\title{
Influence of humic acid supplemented diets on intestinal microbiome and laying performance of egg-type chicken
}

*Agboola, A. F., Omidiwura, B. R. O., Amole, A. O., Olanrewaju, O. A. and Adeniran, Y. E.

Department of Animal Science, University of Ibadan, Ibadan, Oyo state, Nigeria *corresponding author: adebisi.agboola@gmail.com, +234(8)022004830

Abstract

Increasing prevalence of antibiotic resistance due to its indiscriminate use in poultry production is an emerging public health issue. This has prompted research on viable alternatives that will improve production performance of birds. This study was designed to evaluate the effect of humic acid supplemented diets on production performance and microbial load in laying hens. Fifty-four 20-week old Isa brown hens were randomly distributed into three dietary treatments consisted of six replicates with three birds per replicate in a completely randomized design. Treatment 1 was the basal diet (control diet) with no humic acid supplementation while treatments 2 and 3 had the basal diet supplemented with $0.2 \%$ humic acid and $0.4 \%$ humic acid, respectively evaluated in a 42-day feeding trial. Performance parameters were evaluated. On day 42, the egg quality attributes were measured. Birds were slaughtered and digesta samples from the ileum were collected for microbial load count. Data obtained were analyzed using descriptive statistics and ANOVA at $\alpha 0.05$. Birds fed 0.4\% humic acid supplemented diet had the highest final weight (1721 g/bird) and weight gain (97.83g/bird). A decrease in weight was observed in birds fed with $0 \%$ humic acid (-168.17g/bird) and $0.2 \%$ humic acid $(-24.17 \mathrm{~g} / \mathrm{bird})$ supplemented diets. Higher $(P<0.05)$ yolk height and yolk width were recorded in supplemented diets as compared with the control diet. Lowest yolk colour (2.33) was found in the control diet while highest (4.16) in 0.4\% humic acid diet. Similarly, highest $(P<0.05)$ Haugh unit (78.09) and shell weight (7.83g) were recorded in $0.4 \%$ humic acid supplemented diet. Least total heterotrophic count $\left(1.10 \times 10^{2} \mathrm{CFU} / \mathrm{ml}\right)$ was recorded in $0.2 \%$ humic acid diet while highest total Lactobacilli count $\left(0.23 \times 10^{2} \mathrm{CFU} / \mathrm{ml}\right)$ observed in $0.4 \%$ humic acid diet. In conclusion, humic acid supplementation up to $0.4 \%$ can serve as a viable replacement to antibiotic growth promoter for improved gut health and performance of laying birds.

Keywords: Laying hens, Humate, Production performance, Microbiota, Egg quality attributes

\section{Influence des régimes alimentaires enrichis en acide humique sur les performances de ponte et le microbiome intestinal des poules de type ouf}

\section{Résumé}

La prévalence croissante de la résistance aux antibiotiques en raison de son utilisation inconsidérée dans la production avicole est un problème de santé publique émergent. Cela a suscité des alternatives viables qui stimuleront la réponse immunitaire des oiseaux et amélioreront les performances de production. Cette étude a été conçue pour évaluer l'effet des régimes alimentaires enrichis en acide humique sur les performances de production et la charge microbienne chez les poules pondeuses. Cinquante-quatre poules brunes Isa âgées de 20 semaines ont été réparties au hasard dans trois traitements diététiques composés de six répétitions avec trois oiseaux par répétition dans un plan complètement randomisé. Le traitement 1 était le régime de base (régime témoin) sans supplémentation en acide humique, 


\section{Effect of humic acid on performance of laying hens}

tandis que les traitements 2 et 3 avaient le régime de base complété avec 0,2\% d'acide humique et 0,4\% d'acide humique, évalués respectivement dans un essai d'alimentation de 42 jours. Les paramètres de performance ont été évalués. Au jour 42, les attributs de qualité des aufs ont été mesurés. Les oiseaux ont été abattus et des échantillons de digesta de l'iléon ont été collectés pour le décompte de la charge microbienne. Les données obtenues ont été analysées en utilisant des statistiques descriptives et une ANOVA à $\alpha 0,05$. Les résultats ont montré que les oiseaux nourris avec une alimentation enrichie en acide humique à $0,4 \%$ avaient le poids final (1721 g/oiseau) et le gain de poids (97,83 g/oiseau) les plus élevés. Une diminution du poids a été observée chez les oiseaux nourris avec des régimes supplémentés à $0 \%$ d'acide humique (-168,17 g/oiseau) et 0,2\% d'acide humique (-24,17 g/oiseau). Une hauteur et une largeur du jaune plus élevées $(P<0,05)$ ont été enregistrées dans les régimes supplémentés par rapport au régime témoin. Une couleur plus faible du jaune $(2,33)$ a été trouvée dans le régime témoin alors qu'elle était plus élevée $(4,16)$ dans le régime contenant 0,4\% d'acide humique. De même, une unité Haugh $(78,09)$ et un poids de coquille $(7,83 \mathrm{~g})$ plus élevés $(P<0,05)$ ont été enregistrés dans un régime enrichi en acide humique à $0,4 \%$. Le nombre total d'hétérotrophes le plus faible $(1,10 \times 102 \mathrm{cfu} / \mathrm{ml})$ a été enregistré dans un régime contenant 0,2\% d'acide humique, tandis que le nombre total de lactobacilles le plus élevé $(0,23 \times 102 \mathrm{cfu} / \mathrm{ml})$ a été observé dans un régime contenant 0,4\% d'acide humique. En conclusion, une supplémentation en acide humique jusqu'à 0,4\% peut servir de remplacement viable au promoteur de croissance antibiotique pour améliorer la santé intestinale et les performances des oiseaux pondeurs.

Mots clés : Poules pondeuses, humate, performance de production, microbiote, attributs de qualité des œufs

\section{Introduction}

High population growth and growing income lead to increasing demand for poultry products in Nigeria. Thus, intensification of poultry production to meet the demand of ever-increasing human population becomes necessary. As a result of this, antibiotics are often administered to prevent the incidence of diseases, improve nutrient utilization and growth performance of birds (Mathur and Singh, 2005; Stanton, 2013). However, indiscriminate use of antibiotics has undesirable effect on birds, such as residue in the tissues and development of resistance genes and transference of such to human microbiota (Hughes and Heritage, 2004). Therefore, the use of antibiotics as growth promoters has been banned in many countries especially in the European Union (EU, 2006; Castanon, 2007) and followed by a similar legislation by issued in Nigeria by the National Agency for Food and Drug Administration and Control (NAFDAC, 2018). Therefore, poultry researchers and nutritionists are searching for viable alternative feed additives that can conveniently replace antibiotics growth promoters in poultry feed without eliciting negative impact on the food chain (Diarra and Malouin, 2014). There are a number of non-therapeutic alternatives that can serve as alternatives to antibiotic growth promoters in poultry nutrition. Among these are: probiotics and prebiotics (Patterson and Burkholder, 2003; Jung et al., 2008), organic acids (Diebold and Eidelsburger, 2006; Agboola et al., 2015), enzymes (Bedford, 2000), herbs and plant extracts (Demir et al., 2005; Omidiwura et al., 2020) etc. The inclusion of organic acids, such as humic acid, as a feed additive in broiler diets can have multiple health and nutritional benefits (Ozturk et al., 2012; Ragaa and Korany, 2016). 
Humic acid is an organic substance derived from the decomposition of organic matter and having a long molecular chain high in its molecular weight (MacCarthy, 2001). Humic acid has been reported to enhance growth through modifying partitioning of nutrient metabolism in broiler chickens (Abdel-Mageed, 2012; Taklimi et al., 2012) and also has the ability to alter the intestinal microflora by increasing the counts of beneficial bacteria (Schepetkin et al., 2003). They have been used as an a $\mathrm{nt}$ id i a r r e a 1 , a n a $1 \mathrm{ges}$ i c, immunostimulatory and antimicrobial agent in veterinary practices in Europe (EMEA, 1999). It has also been proposed that humic acid plays an effective role in minimizing health problems and potential losses in laying hens (Yoruk et al., 2004; Kucukersan et al., 2005). Against this background, the study was designed to evaluate the effect of humic acid supplementation on laying performance, egg quality attributes and microbial load in laying hens.

\section{Materials and methods Experimental site}

This experiment was carried out at the Poultry Unit, Teaching and Research Farm, University of Ibadan, Oyo State, Nigeria.

Experimental diets and management of birds

Fifty-four 20-week old Isa brown hens from the Poultry Unit, Teaching and Research Farm, University of Ibadan were used for this experiment. The birds were randomly distributed into three dietary treatments sorted by body weight with six replicates comprised of three hens each in a completely randomized design. The birds were housed in a battery cage in a semicontrolled environment. The birds had access to $100 \mathrm{~g}$ of experimental diet per bird per day and water was supplied ad libitum during the study period which lasted for six weeks. The basal diet was a standard commercial bagged layers' mash containing: Crude protein-16.5\%, Calcium$3.6 \%$, Available phosphorus- $0.45 \%$ and Metabolizable energy- 2,500 Kcal/kg in accordance with NRC (1994) guidelines. Treatment 1 was the control diet (basal diet), not supplemented with humic acid. Treatment 2 had basal diet $+0.2 \%$ humic acid while Treatment 3 was a basal diet + $0.4 \%$ humic acid. Respective humic acid concentration was added over the top of the compounded feed.

\section{Data collection}

\section{Feed intake}

Each replicate was supplied $100 \mathrm{~g}$ of feed in the morning and $200 \mathrm{~g}$ of feed in the afternoon making a total of $300 \mathrm{~g}$ of feed per replicate (3 birds) per day. Feed leftover was measured at the end of each week. Weekly feed intake was calculated by subtracting the leftover feed from the feed supplied. Daily feed intake was calculated by dividing the weekly feed intake by 7 .

\section{Weight gain}

The birds were weighed weekly with the use of a sensitive weighing scale to determine the weight of the birds. The weight gain was calculated by subtracting the initial weight from the final weight of the bird.

\section{Feed conversion ratio}

The feed conversion ratio was calculated by dividing the feed intake per bird per week by average egg weight per week multiplied by number of eggs laid per bird per week.

Feed Conversion Ratio $=$ Feed intake per week $(\mathrm{g})$ Average egg weight per week $x$ Number of eggs laid perweek

\section{Egg weight}

Eggs were collected from each replicate daily throughout the experimental period to evaluate the egg weight. The egg weight was measured using a sensitive weighing scale.

\section{Hen day production}

Hen day production was obtained by dividing the number of eggs collected per 


\section{Effect of humic acid on performance of laying hens}

week by number of days in a week multiply by numbers of birds per treatment.

Hen-day production $(\%)=$

Total Number of eggs collected per week $\quad$ x 100

Number of days in a week $x$ Number of birds

\section{Egg quality evaluation}

At day 42 of the experiment, the egg quality parameters were measured. Egg length and width were measured using vernier caliper. The width was measured as the distance between the broad and narrow ends of the eggs. Egg Shape Index was calculated as the percentage of the egg width to the egg length.

Egg Shape Index $=$ Width of egg $(\mathrm{mm}) \times 100$ Length of egg $(\mathrm{mm})$

Yolk height and yolk width were measured using a vernier caliper. Albumen height was measured with tripod micrometer after the egg was gently broken and the maximum height was taken. Yolk index was estimated from ratio of yolk height to yolk width. Yolk colour was determined with a yolk colour fan scale (1 to 15). Haugh unit is a relationship between egg weight and height of thick albumen surrounding yolk. This was calculated using the values obtained from the egg weight and albumen height. This can be expressed as:

$$
\mathrm{HU}=100 \log \left[\mathrm{H}+7.57-1.7 \mathrm{~W}^{0.37}\right]
$$

Where, $\mathrm{H}=$ Albumen Height $(\mathrm{mm})$ and $\mathrm{W}=$ Weight of the egg $(\mathrm{g})$

\section{Microbial load \\ Sample collection and preparation}

Two birds were randomly selected and slaughtered from each treatment. The ileum (the portion of the small intestine extending from the Vitelline diverticulum to read a point of $40 \mathrm{~mm}$ proximal to the ileocaecal junction) was removed. The ileal digesta samples were transferred into syringe, packed in ice and taken to the Environmental Microbiology and Biotechnology Laboratory, Department of Microbiology, University of Ibadan for microbiological analysis.
Laboratory work benches were sterilized using cotton wool dipped in $70 \%$ ethanol. All procedures were carried out under aseptic conditions. The culture media used in this study were weighed out following the manufacturers' instructions, and sterilized at $121^{\circ} \mathrm{C}$ inside an autoclave for 15 minutes. The media used included nutrient agar, eosin Methylene blue (EMB) and MacConkey agar (Oxoid, UK).

\section{Enumeration of the bacterial load of the intestinal content}

The enumeration of the bacterial load in the samples was done using the pour plate technique of Harrigan and MacCance (1966). Aliquot (1mL) of the semi-solid intestinal digests was dispensed into $10 \mathrm{~mL}$ of sterile peptone water, used as the stock. Ten-fold serial dilution was carried out on the sample using peptone water as the diluent. Aliquots (1mL) of the selected dilutions were plated out on the Nutrient agar (for the Heterotrophic bacterial count) and Eosin Methylene Blue (for the E. coli count), MacConkey agar (for the Total coliform). The set up was allowed to set and incubated at $35-37^{\circ} \mathrm{C}$ for $24-48$ hours in the incubator. The plates were observed after the incubation period and observations were noted and recorded.

\section{Chemical analysis}

Proximate analysis of the experimental diets was done to determine the moisture content, crude fiber, ash content, crude protein and ether extract according to the methods described by AOAC (2005).

\section{Statistical analysis}

Data obtained were analyzed using descriptive statistics and ANOVA, using completely randomized design of Statistical Analysis System (SAS, 2008). The treatment means were separated using Duncan's Multiple Range Test (Duncan, 1955) of the same software package to test significant differences $(\mathrm{p}=0.05)$ among the means. Logarithmic $(\log 10)$ transformation was applied for microbial 
colony forming unit (cfu) data.

\section{Results}

Performance characteristics of birds fed with humic acid supplemented diets

The results of performance characteristics of laying birds fed humic acid diets are shown in Table 1. There were no significant $(\mathrm{P}>0.05)$ differences observed in initial weight, feed intake, egg weight, feed conversion ratio and hen day production. However, the final weight and weight changes were significantly $(\mathrm{P}<0.05)$ influenced by humic acid supplementation. Birds on $0.4 \%$ humic acid supplemented diet had the highest final weight (1721 g/bird) and weight gain (97.83g/bird). A decrease in weight was observed in birds fed with $0 \%$ humic acid $(-168.17 \mathrm{~g} / \mathrm{bird})$ and $0.2 \%$ humic acid $(-24.17 \mathrm{~g} / \mathrm{bird})$ supplemented diets.

Table 1. Performance characteristics of laying hens fed humic acid supplemented diets

\begin{tabular}{lccccc}
\hline Parameter & $\begin{array}{c}0 \% \text { humic } \\
\text { acid }\end{array}$ & $\begin{array}{c}0.2 \% \text { humic } \\
\text { acid }\end{array}$ & $\begin{array}{c}0.4 \% \text { humic } \\
\text { acid }\end{array}$ & SEM & P value \\
\hline Initial weight $(\mathrm{g} / \mathrm{bird})$ & 1570.67 & 1540.33 & 1623.17 & 31.93 & 0.2121 \\
Final weight $(\mathrm{g} / \mathrm{bird})$ & $1402.50^{\mathrm{b}}$ & $1516.17^{\mathrm{b}}$ & $1721.00^{\mathrm{a}}$ & 49.06 & 0.0012 \\
Weight change $(\mathrm{g} / \mathrm{bird})$ & $-168.17^{\mathrm{c}}$ & $-24.17^{\mathrm{b}}$ & $97.83^{\mathrm{a}}$ & 45.58 & 0.0033 \\
Feed intake $(\mathrm{g} / \mathrm{b}$ ird $)$ & 637.59 & 651.30 & 639.07 & 7.49 & 0.3886 \\
Egg weight $(\mathrm{g})$ & 54.83 & 58.16 & 57.83 & 0.52 & 0.1642 \\
Feed conversion ratio & 2.31 & 2.27 & 2.27 & 0.12 & 0.9570 \\
Hen day production $(\%)$ & 72.88 & 70.64 & 70.64 & 2.93 & 0.8238 \\
\hline
\end{tabular}

Means on the same row with different superscripts are significantly $(\mathrm{P}<0.05)$ different

\section{Internal and external egg attributes of laying hens fed humic acid supplemented diets}

The result of humic acid inclusion on the attributes of internal and external qualities of egg is presented is Table 2 . There were no significant differences $(\mathrm{P}>0.05)$ observed in yolk weight, yolk index, albumen height, albumen width, egg length, egg width and egg shape index. However, yolk height, yolk width, yolk colour, Haugh unit and shell weight were significantly $(\mathrm{P}<0.05)$ influenced across the treatments. Highest $(\mathrm{P}<0.05)$ yolk height and yolk width were recorded in supplemented diets as compared with the control diet. Lowest yolk colour (2.33) was found in the control diet while highest (4.16) in $0.4 \%$ humic acid diet. Similarly, highest $(\mathrm{P}<0.05)$ Haugh unit (78.09) and shell weight (7.83g) were recorded in $0.4 \%$ humic acid supplemented diet.

Intestinal microbial load in laying hens fed humic acid supplemented diets

The result of humic acid supplementation on the gut microbial load of birds is shown in Table 3. There were no significant $(\mathrm{P}>0.05)$ differences observed in total coliform count and total E. coli count in birds on experimental diets. Least total heterotrophic count $\left(1.10 \times 10^{2} \mathrm{cfu} / \mathrm{ml}\right)$ was recorded in $0.2 \%$ humic acid diet while highest total Lactobacilli count $\left(0.23 \times 10^{2}\right.$ $\mathrm{cfu} / \mathrm{ml}$ ) was observed in $0.4 \%$ humic acid supplemented diet. 


\section{Effect of humic acid on performance of laying hens}

Table 2. Internal and external egg quality parameters of laying hens fed humic acid supplemented diets

\begin{tabular}{llllll}
\hline Parameter & $\begin{array}{l}0 \% \text { humic } \\
\text { acid }\end{array}$ & $\begin{array}{l}0.2^{\%} \text { humic } \\
\text { acid }\end{array}$ & $\begin{array}{l}0.4 \% \text { humic } \\
\text { acid }\end{array}$ & SEM & P value \\
\hline Yolk weight $(\mathrm{g})$ & 13.00 & 13.00 & 13.33 & 0.10 & 0.5486 \\
Yolk height (mm) & $3.87^{\mathrm{b}}$ & $3.98^{\mathrm{a}}$ & $4.00^{\mathrm{a}}$ & 0.04 & 0.0508 \\
Yolk width (mm) & $3.69^{\mathrm{b}}$ & $3.87^{\mathrm{a}}$ & $3.90^{\mathrm{a}}$ & 0.04 & 0.0206 \\
Yolk colour & $2.33^{\mathrm{c}}$ & $3.16^{\mathrm{b}}$ & $4.16^{\mathrm{a}}$ & 0.26 & 0.0163 \\
Yolk index & 1.04 & 1.03 & 1.02 & 0.01 & 0.8145 \\
Albumen height $(\mathrm{mm})$ & 5.54 & 5.54 & 6.10 & 0.10 & 0.1756 \\
Albumen width (mm) & 5.46 & 5.46 & 5.03 & 0.11 & 0.4297 \\
Haugh unit & $74.85^{\mathrm{b}}$ & $73.56^{\mathrm{b}}$ & $78.09^{\mathrm{a}}$ & 0.73 & 0.0212 \\
Egg length (mm) & 5.36 & 5.46 & 5.23 & 0.04 & 0.3398 \\
Egg width $(\mathrm{mm})$ & 4.26 & 4.35 & 4.34 & 0.02 & 0.2737 \\
Egg shape index & 0.79 & 0.79 & 0.83 & 0.01 & 0.2618 \\
Shell weight $(\mathrm{g})$ & $6.50^{\mathrm{c}}$ & $7.33^{\mathrm{b}}$ & $7.83^{\mathrm{a}}$ & 0.12 & 0.0179 \\
\hline
\end{tabular}

Means on the same row with different superscripts are significantly $(\mathrm{P}<0.05)$ different

Table 3. Microbial load $\left(\times 10^{2} \mathrm{CFU} / \mathrm{ml}\right)$ in laying hens fed humic acid supplemented diets

\begin{tabular}{lccccc}
\hline Parameter & $\begin{array}{c}0 \% \text { humic } \\
\text { acid }\end{array}$ & $\begin{array}{c}0.2 \% \text { humic } \\
\text { acid }\end{array}$ & $\begin{array}{c}0.4 \% \text { humic } \\
\text { acid }\end{array}$ & SEM & P value \\
\hline Total Heterotrophic Count & $2.16^{\mathrm{a}}$ & $1.10^{\mathrm{b}}$ & $1.75^{\mathrm{a}}$ & 0.34 & 0.0521 \\
Total Coliform Count & 1.50 & 1.43 & 1.44 & 0.06 & 0.8998 \\
Total E. coli Count & 1.20 & 1.01 & 1.15 & 0.12 & 0.8678 \\
Total Lactobacilli Count & $0.13^{\mathrm{b}}$ & $0.17^{\mathrm{b}}$ & $0.23^{\mathrm{a}}$ & 0.02 & 0.0378 \\
\hline
\end{tabular}

Means on the same row with different superscripts are significantly $(\mathrm{P}<0.05)$ different

\section{Discussion}

Humic acid has been reported to improve performance of poultry through healthy gastrointestinal tract ecosystem (Taklimi et al., 2012). However, there have been inconsistencies in reports on the beneficial effects of humic acid in laying hens. These inconsistent results and different responses of supplementary humic acid might be due to the species, age, sex, plane of nutrition, nutrient composition of the diet, levels of humic acid in the diet, stage of production, the duration of supplementation or environmental conditions. In the current study, humic acid had no significant effect on feed intake, egg weight, feed conversion ratio and hen day production except for final weight and weight changes. There was a depression in the weight of hens on the control diet and $0.2 \%$ humic acid supplemented diet, but significant improvement in birds fed with $0.4 \%$ humic acid supplemented diet. The positive impact of humic acid on body weight may be due to its effect on stabilizing the intestinal microflora and thus ensures an improved utilization of nutrients in the feed, which could lead to an increase in the live body weight of laying hens (Shermer et al., 1998; Humintech, 2004). Result of the present study is in accordance with the studies on the positive effect of humic acid supplemented diets on body weight gain of broiler chickens and quails (Kocabagli et al., 2002; Abdel-Mageed, 2012). However, Karaoglu et al. (2004) and Rath et al. (2006), indicated that diets containing humic acid did not significantly affect 


\section{Agboola, Omidiwura, Amole, Olanrewaju. and Adeniran}

broiler chicken's growth performance. In some studies, humate supplementation of the diets of laying quails (Yalçin et al., 2005), broilers (Yalcin et al., 2003) did not improve the body weight at the end of the experiment. There was no difference in feed intake of laying birds placed on humic acid supplemented diet and the control diet. This shows that the birds tolerated humic acid supplementation in their diets. Similar results were reported by Yoruk et al. (2004); Hanafy and ElSheikh (2008); Sahin et al. (2011); Abdel-Mageed (2012) and Samya (2016). These authors averred that feed consumption was not affected significantly by humic acid supplementation in broiler chickens, laying hens, turkey hens and quails. In addition, Yoruk et al. (2004) asserted that humate with concentration of 0.1 and $0.2 \%$ had no significant effect on feed intake in the late stage of laying hens. Kocabagli et al. (2002) also indicated that humate diets had no positive influence on feed consumption of broiler chickens. However, some researchers reported that dietary humic acid supplementation increased feed intake in laying hens (Hayirli et al., 2005). On the other hand, Kucukersan et al. (2005) showed that the average daily feed consumption of hen fed diets with humic acid was significantly decreased compared with the control group and there was no statistically significant difference in egg weight between the groups.

The results of this current study shows that there was no significant difference in the feed conversion ratio of birds. This agrees with the report of Sahin et al. (2011) and is in disagreement with the findings of Yoruk et al. (2004), which shows that humates promote growth by improving feed conversion ratio. Mirnawati and Marlida (2013) reported that humic acid at a level of $100 \mathrm{ppm}$ in water improved feed conversion ratio in broilers. Also, Samya (2016) reported best feed conversion ratio during all age intervals of birds fed with humic acid supplemented diets compared to control diet. Parks et al. (1986) reported improved digestibility of nutrients, immunity and growth performance of turkey when fed with humate with low and high crude protein diets.

Regardless of humic acid supplementation, overall mean of egg weight and hen day production were not significantly affected in this study. However, it has been reported that addition of humate into layer diets at a level of 30 and $60 \mathrm{mg} / \mathrm{kg}$ (Kucukersan et al., 2005), 90 ppm (Ozturk et al., 2012), up to $0.3 \mathrm{~g} / \mathrm{kg}$ (Hayirli et al., 2005) or $2 \mathrm{~g} / \mathrm{kg}$ (Kucukersan et al., 2004) improved egg production and egg weight. On the other hand, Wang et al., (2006) indicated that the dietary humic substances at 5 or $10 \%$ decreased egg production but egg weight was improved.

Yoruk et al. (2004) found that supplementation of humate in laying hens diets at 0.1 and $0.2 \%$ for 75 days during the late laying period caused egg production increase compared to control group, while, no significant effect on egg weight was observed. In agreement with the present study, Kucukersan et al. (2005) and Yalcin et al. (2005) reported that humate supplementation had no effect on the egg weight of laying hens and quails.

The inclusion of humic acid did not influence most of the eqq quality attributes measured except for yolk height, yolk width, yolk colour, shell weight and Haugh unit. This is in agreement with the findings of Hanafy et al. (2008), who reported no significant differences in egg shape index, albumen percentage and yolk index with humic acid supplementation across the treatments.

The conjugate base of humic acid as used by Macit et al. (2009), reported that yolk colour improved with the supplementation of different levels in layer diets, which is similar with the findings of this study but in contrast with the reports of Dobrzańsk et al. 


\section{Effect of humic acid on performance of laying hens}

(2009), that yolk colour did not improve with supplementation of humic acid. In the present study, improved Haugh unit was observed in $0.4 \%$ humic acid diet, which is contrary to the findings of Abo-Egla et al. (2011) who reported no significant effect of humic acid on egg shape index, albumen $(\%)$, Haugh unit and egg yolk index when $0.1,0.2$ and $0.3 \%$ humic acid was fed to laying hens. According to Arafat et al. (2015), humic acid supplementation did not positively influence the Haugh unit and albumen height of laying hens when 2.0, 4.0 or $6.0 \mathrm{mg}$ of humic acid per $\mathrm{kg}$ was added in drinking water.

Acidification of diets with weak organic acids has been reported to decrease the colonization of pathogens (Kirchgessner and Roth, 1988). Scientific findings on the impacts of humic substance on gut health and composition of microbiota in the gastrointestinal tract have been reported (Shermer et al., 1998; Tikhonova et al., 2010; Mudroňová et al., 2020). Results of the current study show that feeding $0.4 \%$ humic acid supplemented diets had significant effect on the total Lactobacilli. This is similar to the findings of Mudroňová et al. (2020) on slight increase in lactic acid bacteria count and decrease in Enterobacteria counts when broiler chicks were fed $0.8 \%$ humic substances. The results of this study are at variance with the findings of Pirgozliev et al. (2008), on reduction in the population of coliform and Lactobacillus counts in the ileum and caeca of broiler chickens fed with organic acid supplemented diet. Also, Ramarao et al. (2004) reported reduction in coliform count in broiler chicken when fed with acidifier at the rate of $300 \mathrm{~g} / 100 \mathrm{~kg}$ feed.

\section{Conclusion}

This study has demonstrated the effect of dietary humic acid supplementation on laying performance, egg quality parameters and microbial load of egg-type chicken. The results show that $0.4 \%$ humic acid supplementation improved final weight, body weight gain and some egg attributes of laying hens. An increased Lactobacillus count in humic acid diet positively correlated with enhanced gut health of the birds. Therefore, humic acid supplementation up to $0.4 \%$ should be encouraged, as this could serve as a viable alternative to antibiotic growth promoter for improved production performance and enhanced gut integrity of laying hens.

\section{References}

Abdel-Mageed, M. 2012. Effect of using organic acids on performance of Japanese quail fed optimal and suboptimal energy and protein levels 2. Butyric acid. Egypt Poult. Sci. J., 32:625-644.

Abo-Egla, E. H., Ismail, F. S. A., Abd ElGhany, F. A. and M. H.Assar, M. H. 2011. Effect of humic acid and biomos supplementation on egg production and quality parameters in local hens. J. Anim. Poult. Prod., 2(4): $55-63$.

Agboola, A. F., Omidiwura, B. R. O., Odu, O, Popoola, I. O. and Iyayi, E. A. 2015. Effect of organic acid and probiotic on performance and gut morphology in broiler chickens. South African Journal of Animal Science, 45 (5): 494-501 http://dx.doi.org/10.4314/sajas.v45i 5.6.

AOAC. 2005. Official Method of Analysis, $18^{\text {th }}$ edition; Association of Official Analytical Chemists. Gathersburg, USA.

Arafat, R. Y., Khan, S. H., Abbas, G. and Iqbal, J. 2015. Effect of dietary humic acid via drinking water on the performance and egg quality of commercial layers. American Journal of Biology and Life Sciences. 3(2): 26-30. 
Bedford, M., 2000. Removal of antibiotic growth promoters from poultry diets: Implications and strategies to minimize subsequent problems. World's Poult. Sci. J. 56:347-365.

Castanon, J. I. R., 2007. History of the use of antibiotic as growth promoters in European poultry feeds. Poultry Science, 86(11): 2466-2471. https://doi.org/10.3382/ps.200700249

Demir, E., Sarica, S., Ozcan, M. A. and Suicmez, M., 2005. The use of natural feed additives as alternatives for an antibiotic growth promoter in broiler diets. Arch. Geflügelk., 69 (3): S110-116.

Diarra, M. S. and Malouin, F. 2014. Antibiotics in Canadian poultry productions and anticipated alternatives. Front Microbiol., 5:282. DOI: $10.3389 /$ fmicb.2014.00282

Diebold, G. and Eidelsburger, U. 2006. Acidification of diets as an alternative to antibiotic growth promoters. In: Antimicrobial growth promoters. Wageningen Academic Publishers, The Netherlands, 311327.

Dobrzański Z., Tadeusz T., Eugeniusz H., Józefa K., Przemysław T. 2009. Effect of humic preparations on productivity and quality traits of eggs from green leg partridge hens. Ann. Anim.Sci., 9(2):165-174.

Duncan, D. B.,1955. Multiple range and Ftest. Biometrics, 11:1-42.

EMEA, 1999. Humic acids and their sodium salts, summary report. Committee for Veterinary Medicinal Products. Eur. Agency Eval. Med. $\begin{array}{llll}P & r & O & d\end{array}$ http://www.emea.eu.int/pdfs/vet/mrl s/055499en.pdf Accessed January 10,2020

EU. 2006. Commission of the European Communities, Commission Regulation No. 1831/2003. Official
Journal of European Union, 268: 29-43.

Hanafy, M. M. and El-Sheikh A. M. 2008. The effect of dietary humic acid supplementation on some productive and physiological traits of laying hens. Egypt. Poult. Sci., 28(4):10431058.

Harrigan, W. F and McCance, M. E. 1966. Laboratory methods in microbiology. Academic Press, Cambridge, 54: 970.

Hayirli, A., Esenbuga, N., Macit, M., Lacin, E., Karaoglu, M., Karaca, H. and Yildiz, L. 2005. Nutrition practice to alleviate the adverse effects of stress on laying performance, metabolic profile, and egg quality in peak producing hens: the humate supplementation. Asian Austr. J. Anim. Sci., 18: 1310-1319.

Hughes, P. and Heritage, J. 2004. Antibiotic growth-promoters in food animals. Assessing quality and safety o f a n i m a 1 f e e d s. http://www.fao.org/3/y5159e/y5159 e08.htm\#bm

Humintech, 2004. Humin animal feed supplements and veterinary medicine and humic acid-based products. Humintech-Humintech $\mathrm{GmbH}$, Heerdter Landstr. 189/D, D40549 Dusseldrof, Germany.

Jung, S. J., Houde, R., Baurhoo, B., Zhao, X. and Lee, B. H. 2008. Effects of galacto oligosaccharides and a Bifidobacteria lactis-based probiotic strain on the growth performance and fecal microflora of broiler chickens. Poultry Science, 87: 16941699.

Karaoglu, M., Macit, M., Esenbuga, N., Durdag, H., Turgut L. and Bilgin, O. C. 2004. Effect of supplemental humate at different levels on the growth performance, slaughter and carcass traits of broilers. Int. J. Poult. Sci., 3: 406-410. 


\section{Effect of humic acid on performance of laying hens}

Kirchgessner, M. and Roth, F. X. 1988. Energy value of organic acids in the rearing of piglets and the fattening of pigs. Übersichten zur Tierernährung 16: 93-108.

Kocabagli, N., Alp, M., Acar, N. and Kahraman, R. 2002. The effects of dietary humate supplementation on broiler growth and carcass yield. Poult. Sci., 81:227-230.

Kucukersan, S., Kucukersan, K., Goncuoglu, E. and Sahin, T. 2004. The effects of dietary humate supplementation on laying hen egg production and egg quality. Indian Vet. J., 81: 674-678.

Kucukersan, S., Kucukersan, K., Colpan, I., Goncuoglu, E., Reisli, Z. and Yesilbag, D. 2005. The effects of humic acid on egg production and egg traits of laying hen. Vet. Med., 50: 406-410.

MacCarthy, P. 2001. The principles of humic substances. Soil Sci., 166: 738-751.

Macit M., Saban C., Nurinisa E., Hatice K. 2009. Effects of dietary humate supplementation on performance, egg quality and egg yolk fatty acid composition in layers. J. Sci. Food Agric. 89(2): 315-319.

Mathur, S. and Singh, R. 2005. Antibiotic resistance in food lactic acid bacteria-a review. International Journal of Food Microbiology, 105(3): 281-295.

Mirnawati, Y. R. and Marlida Y. 2013. Effects of humic acid addition via drinking water on the performance of broilers fed diets containing fermented and non-fermented palm kernel cake. Archiva Zootechnica, 16(1): 41-53.

Mudroňová, D., Karaffová, V., Pešulová, T., Koščová, J., Maruščáková, I. C. and M. Bartkovský, M. 2020. The effect of humic substances on gut microbiota and immune response of broilers. Food and Agricultural Immunology, 31(1): 137-149. https://doi.org/10.1080/09540105.2 $\underline{019.1707780}$

NAFDAC. 2018. National Agency for Food and Drug Administration and Control (Press release on antimicrobial resistance. July 25, 2018. https://punchng.com/nafdacbans-use-of-antibiotics-in-animalfeed/Accessed 10 January 2020.

NRC. 1994. National Research Council, Nutrient Requirements of Poultry. 9th Revised Edition. National Academy Press, Washington DC.

Omidiwura, B. R. O., Agboola, A. F., Omotosho, O. Y and MustaphaOlosho, J. A. 2020. Influence of Diets Supplemented with Carica papaya and Chromolaena odorata Leaf Meals on Performance, Blood Profile and Gut Integrity of Broiler Chickens. Journal of Animal Science and Veterinary Medicine, 5(5): 173-183.

Ozturk, E., Ocak, N., Turan, A., Erener, G., Altop, A. and Cankaya, S. 2012. P e r formance, c a r c a s s, gastrointestinal tract and meat quality traits, and selected blood parameters of broilers fed diets supplemented with humic substances. J. Sci Food Agric. 92: 59-65.

Parks, C., Ferket, P. R., Thomas L. N. and Grimes J. L. 1986. Growth performance and immunity of turkey fed high and low crude protein diets supplemented with Menefee humate. Poult. Sci.,75:138-14.

Patterson, J. A. and Burkholder, K. M. 2003. Application of prebiotics and probiotics in poultry production. Poultry Science, 82: 627-631.

Pirgozliev, V., Murphy, T. C., Owens, B., George, J. and McCannin, M. E. E. 2008. Fumaric and sorbic acid as additives in broiler feed. Res. Vet. 
Sci., 84, 387-394.

Ragaa, N. M. and Korany. R. M. S. 2016. Studying the effect of formic acid and potassium diformate on performance, immunity and gut health of broiler chickens. Anim. Nutr., 2:296-302.

Ramarao, S.V., Reddy, M.R. Rajuand, M.V.L.N. and Panda, A.K. 2004. Growth, nutrient utilization and immune-competence in broiler chicken fed probiotic, gut acidifier and antibacterial compounds. Indian J. Poult. Sci., 39: 125-130.

Rath, N. C., Huff, W. E. and Huff. G. R. 2006. Effects of humic acid on broiler chickens. Poult. Sci., 85: 410-414.

Sahin, T., EImal, D., Kaya, I., Sar, M. and Kaya, O. 2011. The effect of single and combined use of probiotic and humate in quail diet on fattening performance and $\mathrm{c}$ a $\mathrm{r}$ c parameters. Kafkas Universitesi Veteriner Fakultesi Dergisi., 17(1):15.

Samya E. I. 2016. Effect of dietary humic acid supplementation on egg production, egg quality and fertility of turkey hens. J. Anim.Poult. Prod.,7(2): 59-65.

SAS. 2008. Statistical Analysis System, SAS users guide: Statistics. SAS institute Inc. Cary, N.C. USA.

Schepetkin, I. A., Khlebnikov, A. I., Ah, S. Y., Woo, S. B., Jeong, C. S., Klubachuk, O. N. and Kwon, B. S. 2003. Characterization and biological activities of humic substances from mumie. J. Agric. Food Chem., 51:5245-5254.

Shermer, C. L., Maciorowski, K. G., Bailey, C. A., Byers, F. M. and Ricke, S. C. 1998. Caecal metabolites and microbial populations in chickens consuming diets containing a mined humate compound. J. Sci. Food Agric., 77: 479-486.

Stanton, T. B. 2013. A call for antibiotic alternatives research. Trends in Microbiology, 21(3): 111-113.

Taklimi, S. M., Ghahri, H. and Isakan, M. A. 2012. Influence of different levels of humic acid and esterified glucomannan on growth performance and intestinal morphology of broiler chickens. Agric. Sci., 3: 663-668.

Tikhonova, V. V., Yakusheva, A. V., Zavgorodnyayaa, Y. A., Byzova, B. A. and Demin, V. V. 2010. Effects of humic acids on the growth of bacteria. Eurasian Soil Science, 43 ( 3 ): $305-313$ D O I : 10.1134/S1064229310030087.

Wang, Q., Yoo, J. S., Chen, Y. J., Kim, H. J., Cho, J. H., Min, B. J., Park, B. C. and Kim, I. H. 2006. Effects of supplemental humic substances on egg production and quality in laying hens. Korean J. Poult. Sci., 33: 317 321.

Yalcin, S., Şehu, A., Onbaşılar, E. and Şahin T. 2003. The effects of dietary humate and probiotic supplementation on performance of broiler. Vet. J. Ankara Univ., 50: 239244.

Yalcin, S., Ergun, A., Erol, H., Yalcin, S. and Ozsoy, B. 2005. Use of Lcarnitine and humate in laying quail diets. Acta. Vet. Hung., 53: 361-370.

Yoruk, M. A., Gul, M., Hayirli, A. and Macit, M. 2004. The effects of supplementation of humate and probiotic on egg production and quality parameters during the late laying period in hens. Poult. Sci., 83: 84-88.

Received: $4^{\text {th }}$ August, 2021 Accepted: $15^{\text {th }}$ December, 2021 